\title{
PRINCIPLES AS SOURCES OF INTERNATIONAL LAW (WITH SPECIAL REFERENCE TO GOOD FAITH)
}

\author{
by Robert Kolb*
}

1. Concepts of source and of 'norm-source'

1.1 Concept of source in a diachronic perspective

1.2 Definition of the term 'source'

1.3 Sources as covering all law-in-movement

1.4 General principles as law-creating arguments

1.5 General principles as 'norm-sources'

1.6 Sources of law/of obligation

2. Concept and applications of good faith

2.1 Three concepts of good faith

2.1.1 Good faith in a subjective sense

2.1.2 Good faith in the sense of an open-ended legal standard

2.1.3 Good faith as a general principle of law

2.2 Judicial practice for good faith as a principle of law

2.2.1 Good faith as principle protecting legitimate expectations

2.2.2 Good faith as prohibiting abuse of rights

2.2.3 Good faith as a source of legal development and of gap-filling

3. Constitutional functions of general principles of law in the international system

3.1 Introductory remarks

3.2 Constitutional functions of principles

3.2.1 Unification of the legal system

3.2.2 Flexibilization of the legal system

3.2.3 Value-catalysers of the legal system

3.2.4 Dynamic and evolutionary function

3.2.5 Guide to interpretation and corrective function

3.2.6 Autonomous source of law (choice of law)

3.2.7 Necessary complement to a series of legal rules

3.2.8 Facilitation of legislative compromises

4. Conclusion

Professor of International Law at the Universities of Neuchâtel, Berne and Geneva (University Centre for International Humanitarian Law).

Netherlands International Law Review, LIII: 1-36, 2006

(C) 2006 T.M.C. Asser Instituut and Contributors

DOI: $10.1017 / \mathrm{S} 0165070 \mathrm{X} 06000015$ 


\section{CONCEPTS OF SOURCE AND OF 'NORM-SOURCE'}

\subsection{Concept of source in a diachronic perspective}

There is a wide array of meanings attached by legal science to the concept of 'source' (fontes). Some of these meanings, of more positivistic obedience, are narrower; some other meanings are less confined, and stretch eventually to containing some directives for the legislator. The term 'source' is a starting point (archai) for the legal science; it discloses the exact substance, which at different times is thought to be part of the province of law and/or of the legal science; conversely, it excludes the substance which is not so found to be part of the legal realm.

For a long time, especially in the middle ages, the term 'source' was used in a very loose sense. It contained all the formal enactments and also the material values and criteria upon which the jurisprudence was at that time erected. ${ }^{1}$ In the time of enlightenment, when the legal science was directed in the first place to the legislator, the theory of sources came to be concentrated on constitutional law, on codification of private law and on legal policy; hence also the general and abstract form of reasoning, which is less understandable if it was to be directed to the judge, but which fits perfectly if it is understood as policy indications for the legislator. ${ }^{2}$ During the nineteenth century, after the demise of the rationalistic natural law school and in parallel with the progress of state-centered positivism, the common use of the term 'source' came to be more limited. Its essential function was at that time to distinguish the law in force from the law to come, the lex lata from the lex ferenda. The aim was to achieve legal certainty, necessary in the modern liberal society dominated by industry and commerce. ${ }^{3}$ Legal science turns at that time deliberately to the judge, searching to constrain its activity to mere reproduction of what the legislator had issued, the judge being ideally what Montesquieu had already termed 'la bouche qui prononce

1. See, e.g., A. Cavanna, Storia del diritto moderno in Europa - Le fonti e il pensiero giuridico, Vol. I (Milan, Giuffrè 1982) pp. 105 et seq. and P. Grossi, L'ordine giuridico medievale (Rome, Laterza 1995). See also the encyclopedic work of W. Fikentscher, Methoden des Rechts, Vol. I (Tübingen, Mohr 1975) pp. 343 et seq. (roman law), 377 et seq. (scolastic method and mos gallicus), 412 et seq. (era of the modern codifications); L. Lombardi, Saggio sul diritto giurisprudenziale (Milan, Giuffrè 1975); and C.K. Allen, Law in the Making, 6th edn. (Oxford, Oxford University Press 1958).

2. See, e.g., H. Coing, Die obersten Grundsätze des Rechts (Heidelberg, Schneider 1947) pp. 150 et seq. More generally, see G. Tarello, Storia della cultura giuridica moderna (Bologna, Il Mulino 1976) pp. 97 et seq.; E. Opocher, Lezioni di filosofia del diritto (Padova, Cedam 1983) pp. 101 et seq. For more detailed studies, see the works of P. Caroni on codification, e.g., P. Caroni, Gesetz und Gesetzbuch (Basel, Helbling \& Lichtenhahn 2003), with references to his earlier writings and other texts.

3. See, e.g., W. Wilhelm, Zur juristischen Methodenlehre im 19. Jahrhundert (Frankfurt, Klostermann 1958). 
les paroles de la loi'. ${ }^{4}$ The wider notion of sources, containing all the legally relevant ideas, values and arguments, even if not yet given a positive form, was in demise. This is especially true for the continental legal systems, whereas in the common law systems the reduction of the law-creating agencies never took the same extent. The term 'sources' (or formal sources) has since become one of the guardians of positive-law orthodoxy. It is, however, not to be confused with theoretic positivism, even if it often is: the science of positive law concerns the places where to find the law in the practical administration of it, and tends to limit them to a given set of formal agencies; theoretic positivism concerns the ultimate foundation upon which the law rests, holding that any enactment of the omnipotent legislator is valid if only it is adopted in the lawfully provided procedure, completely irrespective of content.

As can be guessed from what precedes, the doctrine of 'sources' as defined in a legal system is a radiography of two elements: first, of the exact concept of law cherished in a particular society at a given time, a concept which can be wider or narrower; second, of the structure of a given society, centralized or decentralized, authoritarian or liberal, since the sources are not a mere technique but also an expression of power as prevailing in a given society. The power to make the law is not merely a technicality; it expresses more generally the power-distribution in a given society.

\subsection{Definition of the term 'source'}

There are many modern definitions of sources, be it in general or in the particular field of international law. We will here focus on the last ones. Brownlie defines the term source as follows: "[T]hose legal procedures and methods for the creation of rules of general application which are legally binding on the addressees.' 5 In the new law dictionary edited by Salmon, the term is defined as 'ensemble de procédés prévus au sein d'un ordre juridique donné pour la création et la modification des normes appartenant à cet ordre' ${ }^{6}$ Morelli, with his usual precision, defines the sources as facts to which a legal order through apposite norms grants the power to create, modify or extinguish legal norms. ${ }^{7}$

The idea emerging out of the preceding definitions can be put in two different but interrelated perspectives: actively speaking, a source determines the means

4. Montesquieu, De l'esprit des lois, liv. XI, Cap. VI.

5. I. Brownlie, Principles of Public International Law, 5th edn. (Oxford, Clarendon Press 1998) p. 1. The sources thus deal with the 'law-creating processes': G. Schwarzenberger, International Law - As Applied by International Courts and Tribunals, Vol. I (London, Stevens 1957) p. 26.

6. J. Salmon, ed., Dictionnaire de droit international public (Brussels, Bruylant 2001) pp. 1041-1042.

7. G. Morelli, Nozioni di diritto internazionale, 7th edn. (Padova, Cedam 1967) p. 21. 
of creating the law; passively speaking, it indicates the place where to find the law. ${ }^{8}$ When merging the two elements, one gets to the definition of Akehurst, defining the sources as "the criteria under which a rule is accepted as valid in the given legal system at issue'. ${ }^{\text {? }}$

All these definitions are quite narrow. Their aim is to clearly delimit the positive law from the rest of social norms. It is, as was correctly pointed out by the last edition of the Oppenheim, to sever the existing law from any other extra-legal elements: "Nevertheless, the concept of a "source" of a rule of law is important, since it enables rules of law to be identified and distinguished from other rules (in particular from rules de lege ferenda) and concerns the way in which the legal force of new rules of conduct is established and in which existing rules are changed.' ${ }^{10}$ Here then is the main function of the modern doctrines of sources: to distinguish the 'is' from the 'ought', the positive from the 'extra-positive', the relevant from the irrelevant. In that sense, the modern doctrines of sources operated a great deal of reduction of the real life of the law, which was pressed into the Procrustean Bed of some formal avenues of lawcreating agencies; the rest being largely relegated beyond the law. ${ }^{11}$

In fact, it was re-discovered during the twentieth century that the law cannot be pressed into such narrow confines, ${ }^{12}$ that the legal argument is much more complex and has constantly recourse to extra-positive elements, which melt with the positive ones into a single process; and that these extra-legal factors are not entirely subjective but flow into the law by way of certain strong arguments or topoi, concentrated into a series of value-oriented general principles and maxims, which tend to provide them with a form of legal-axiological clothing. Thus, the inherited concept of legalist positivism (no law beyond the express

8. The two perspectives need not necessarily be the two sides of the same coin, since you may have rules which are not created by a process of legislation, but which simply exist: e.g., general principles of law, found by way of comparative law.

9. P. Malanczuk, ed., Akehurst's Modern Introduction to International Law, 7th edn. (London, Routledge 1997) p. 35.

10. R.Y. Jennings and A. Watts, eds., Oppenheim's International Law, 9th edn. (London, Longman 1992) p. 23. See also, e.g., Malanczuk, ed., op. cit. n. 9, at p. 35: 'These criteria [those of the sources] distinguish binding law from legally non-binding other social or moral norms and the law de lege lata (the law as it currently stands) from the law de lege ferenda (the law as it may be, or should be, in the future).'

11. For a lucid criticism of this course, see J. Esser, Grundsatz und Norm in der richterlichen Fortbildung des Privatrechts, 4th edn. (Tübingen, Mohr 1990). And see already F. Gény, Méthode d'interprétation et sources en droit privé positif, 2nd Vol. (Paris, LGDJ 1932).

12. See, e.g., especially for the civil law systems, Esser, op. cit. n. 11, particularly pp. 1 et seq., 69 et seq., 87 et seq., 242 et seq., 267 et seq., 289 et seq., 327 et seq.; R. Dworkin, 'Is Law a System of Rules?', in R. Summers, ed., Essays in Legal Philosophy (Oxford, Basil Blackwell 1968) pp. 25 et seq.; R. Dworkin, Taking Rights Seriously (London, Duckworth 1977) pp. 22 et seq.; R. Alexy, 'Zum Begriff des Rechtsprinzips', in W. Krawietz, et al., eds., Argumentation und Hermeneutik in der Jurisprudenz, Rechtstheorie, Suppl. 1 (Berlin, Duncker \& Humblot 1979) pp. 59 et seq.; U. Penski, 'Rechtsgrundsätze und Rechtsregeln', 44 Juristenzeitung (1989) pp. 112-113. 
setting of the legislator) was successfully challenged. The modern theories of legal hermeneutics found here their point of departure. ${ }^{13}$

\subsection{Sources as covering all law-in-movement}

In a broader sense, as the one usually used and still prevalent in international law (formal law-creating agencies), the term 'source' may well design all elements which concur to the development of the law, i.e., all aspects that involve some element of legal creativity. Thus, the term would not remain confined to the formal avenues of legislation, but opened up to that whole field of quasi-legislation which is linked to the law-application. In effect, as modern hermeneutics have shown, there is no law-application which does not add some fresh elements to the norm which it applies. This creativity are particularly striking in the case of very general norms and principles, especially of constitutional type, e.g., in the field of human rights or in the field of the Charter of the United Nations. Thus, for example, the right to a fair trial as enshrined in Article 6 of the European Convention of Human Rights, has been enriched by a whole body of case-law, developing the quite short-phrased conventional guarantees; or, the highly political interpretations and developments of the Charter law, such as the 'Uniting for Peace Resolution' of $1950,{ }^{14}$ shifting the main power

13. For such theories, see among many others: K. Larenz, Methodenlehre der Rechtswissenschaft, 6th edn. (Berlin, Springer 1991) pp. 11 et seq., 283 et seq., 312 et seq., 366 et seq.; A. Kaufmann and W. Hassemer, eds., Einführung in Rechtsphilosophie und Rechtstheorie der Gegenwart, 4th edn. (Heidelberg, C.F. Müller 1984) pp. 94 et seq., 113 et seq., 193 et seq., 225 et seq., 276 et seq., 389 et seq.; W. Fikentscher, Methoden des Rechts in vergleichender Darstellung, 5 vols. (Tübingen, Mohr 1975-1977) Vols. III and IV; F. Müller, Juristische Methodik, 6th edn. (Berlin, Duncker \& Humblot 1995); M. Kriele, Theorie der Rechtsgewinnung (Berlin, Duncker \& Humblot 1967) pp. 67 et seq.; W. Hassemer, ed., Dimensionen der Hermeneutik (Heidelberg, R. v. Decker \& C.F. Müller 1984); J. Hruschka, Das Verstehen von Rechtstexten (Munich, Beck 1972); J. Hruschka, 'Rechtsanwendung als methodologisches Problem', 50 Archiv für Rechts- und Sozialphilosophie (1964) pp. 485 et seq.; A. Kaufmann, Beiträge zur juristischen Hermeneutik, 2nd edn. (Cologne, Heymanns 1993); H.G. Hinderling, Rechtsnorm und Verstehen (Berne, Stämpfli 1971); F. Bydlinski, Juristische Methodenlehre und Rechtsbegriff, 2nd edn. (Vienna, Springer 1991); J. Esser, Vorverständnis und Methodenwahl in der Rechtsfindung (Frankfurt, Athenäum Verlag 1970); K. Engisch, Logische Studien zur Gesetzesanwendung, 3rd edn. (Heidelberg, Winter 1963), particularly pp. 15 et seq.; C. Perelman, Logique juridique (Paris, Dalloz 1976) pp. 70 et seq., 81 et seq.; C. Perelman and L. Olbrechts-Tyteca, Traité de l'argumentation, Vol. I (Paris, Presses Universitaires de France 1970); S. Belaid, Essai sur le pouvoir créateur et normatif du juge (Paris, LGDJ 1974); R. Alexy, A Theory of Legal Argumentation (Oxford, Clarendon Press 1989); D. Bourcier and P. Mackay, Lire le droit; langue, texte, cognition (Paris, LGDJ 1992), particularly pp. 41 et seq., 121 et seq.; M. Ascoli, La interpretazione delle leggi, (Milan, Giuffrè 1991), particularly pp. 13 et seq.; E. Betti, Zur Grundlegung einer allgemeinen Auslegungslehre (Tübingen, Mohr 1988); E. Betti, Allgemeine Auslegungslehre als Methodik der Geisteswissenschaften (Tübingen, Mohr 1967) pp. 42 et seq.; A. Aarnio, Le rationnel comme raisonnable: la justification en droit (Brussels, LGDJ 1992).

14. Allowing the General Assembly of the United Nations, under certain conditions, to 
distribution within the United Nations in a way more favorable to the General Assembly; or, the interpretation of Article 42, construed as allowing a delegation of military enforcement powers to member states of the organization, ${ }^{15}$ or else, by the development of a doctrine of implied powers, as was done by the International Court in the Reparation for Injuries case (1949). ${ }^{16}$

Such development of the legal content of a norm is not absent also in other cases, where apparently it is less visible. In any case of dispute as to the application to a norm there is at least some degree of uncertainty as to the correct application of the norm. Consequently, the judgment rendered will add something to the previous state of affairs. It will clarify the sense of the norm in a given set of circumstances; or permit to reconsider its precise scope of application, its relation to other norms; or permit the drawing of arguments of analogy or delimitation. This function is performed by all jurisprudence and also by all other form of law-application, e.g., by direct inter-governmental exchanges. Nowhere else, however, is it more visible than in the case of reasoned adjudication, such as performed by tribunals. ${ }^{17}$

Thus, for example, a whole series of uncertainties as to the procedural law to be followed in its fore have been settled by the International Court in its rich jurisprudence, since the times of the Permanent Court of International Justice. ${ }^{18}$ Or, else, the Greek-German mixed arbitral tribunal applied the rule of prohibition of indiscriminate bombings to bombings from the air, notwithstanding the special difficulties which prevailed under that perspective $;{ }^{19}$ it thereby extended and reinforced a rule that formerly had been applied only to soil-soil bombings. And when the Court found in the Rights of United States Nations in Morocco (1952) that the relevant conventions had not intended to recognize any preexisting consular rights of capitular type, but had only intended to regulate these rights as far as they were still existing, ${ }^{20}$ a general indication of policy was implicit in it, going far beyond the particular case and the particular treaties:

recommend the use of force in the case of a threat to peace, a breach of peace, or an act of aggression. Resolution 377 (V) of 3 November 1950.

15. See D. Sarooshi, The United Nations and the Development of Collective Security: The Delegation by the United Nations Security Council of its Chapter VII Powers (Oxford, Oxford University Press 1999).

16. ICJ Reports (1949) pp. 178 et seq.

17. See the many examples in H. Lauterpacht, The Development of International Law by the International Court (London, Stevens 1958).

18. See, e.g., G. Guyomar, Commentaire du Règlement de la Cour internationale de Justice, Interprétation et pratique (Paris, Pédone 1983). See also S. Rosenne, The Law and Practice of the International Court, 1920-1996, 3rd edn., Vol. II (Jurisdiction) and Vol. III (Procedure) (The Hague, Nijhoff 1997) and H. Thirlway, 'The Law and Procedure of the International Court of Justice, 1960-1989, Part Twelve', 72 BYIL (2001) pp. 37 et seq.

19. See, e.g., Coenco frères v. Allemagne (1927), Recueil des décisions des tribunaux arbitraux mixtes, Vol. 7, p. 683.

20. ICJ Reports (1952) p. 196. 
namely that the Court was not inclined to look favorably to these vestiges of colonialism, and that a narrow interpretation would be followed.

The thumb rule is thus that there is no law-application (except the most mechanical in the most easy cases) without some law-creation; in other words that there is no law-application without some element of legislation; and that this is true even if the degree of legislation implicit in application is ancillary, fragmentary and its force limited to the specific case at stake. The question is where to take the elements in order that this ancillary law-creation does not rest on entirely speculative and subjective reasoning. The general principles of law and other legal maxims (or 'strong arguments', topoi) have here an important role to play.

\subsection{General principles as law-creating arguments}

Seen under the perspective just mentioned, the general principles of law play a prominent role in this particular field of law-creation. They are elements of law-creation and of law-creativity, inspiring as much the legislator as the lawapplier. Their main characteristic is to be general, i.e., open to value-oriented arguments: principles are thus in the first place 'transformators' of extra-positive (moral, social, or other) needs into the legal system. ${ }^{21}$ After some time of incubation, a new legal idea, pressed by social needs, breaks through in some argument to be made in a suitable case; this general idea, yet devoid of any special legal clothing, can at that stage find an ally only in some general principle of the legal system. By reason of the fundamental analogy of the main situations of life of man, some principle will suit this new legal idea. It will thus, in the legal argument, be clothed under the guise of the principle, e.g., responsibility for risk, proportionality, separation of powers, good faith (e.g., legitimate expectations), or even the concepts of 'reasonableness', equity, naturalis ratio. From that moment on, the principle will have been enriched by a further content, which will then be integrated into it by scientific work and analysis. Conversely, and by the same token, the principle can be seen as having furnished to the new legal need a basis of deductive reasoning: a solution suiting the new need was obtained by subsuming it under the principle, by some way of deduction, or reception. Thus, for example, the rules as to the reparation of the damages caused were, in international law as in the other systems based on case-law, developed out of a set of general principles, mainly the ideas of equivalence (reciprocity), of proportionality, of nemo ex propria turpitudine commodum capere potest, of equity and of retribution. Or, further example, the law of armed conflicts all emerged out of a re-elaboration of the principles of military necessity, of mercy and compassion (no excessive sufferings, no useless destruction, humane treatment) and of proportionality. All the law of

21. See Esser, op. cit. n. 11, at pp. 50 et seq. 
armed conflicts is but a sort of mise en équilibre of these three legal ideas.

On the other hand, these principles offer the advantage of not being completely open-ended. They have been given some form of soft positive clothing, in order that the recourse to them be felt as sufficiently controlled. A core meaning has attached to them, often in many centuries of legal developments. Thus, the principle of good faith, as will later be discussed, has coagulated within its borders the legal ideas (1) of the protection of legitimate expectations (e.g., through doctrines such as qualified acquiescence, qui tacet consentire videtur...; of estoppel; of responsabilté pour apparence créee); (2) of protection of inter-personal or social finalities attached to legal institutions or instruments through the doctrines of prohibition of abuse of rights or détournement de pouvoir; (3) and finally of some standard of moral correctness and reciprocity, by way of doctrines such as 'none shall take profit of his own wrong'. These facets of the principle were attached to it by way of prolonged jurisprudence. The same could be said for the principle of proportionality. Several legal ideas coagulated in it, during the nineteenth and twentieth century. First, there is the idea that a measure taken should be able to fulfil the aim searched for; otherwise, if it does not have that ability, it will also be disproportionate. Second, the idea that among the several means able to further the aim searched for, the least onerous means should be selected (idea of "necessity'). Third, the idea that there must be some degree of equivalence in gravity between a measure taken and the fact or act giving rise to it. ${ }^{22}$ Again, it was in practice that these aspects were slowly worked out as requirements of reason. ${ }^{23}$

22. See R. Kolb, 'La proportionnalité dans le cadre des contre-mesures et des sanctions essai de clarification conceptuelle', in L. Forlati-Picchio and L.A. Sicilianos, eds., Les sanctions économiques du point de vue du droit international, public et privé (Leiden, Nijhoff 2004) pp. 383-386.

23. As to the way of this channeling of ideas through principles in the forensic practice, see, e.g., H. Henkel, Einführung in die Rechtsphilosophie, 2nd edn. (Munich, Beck 1977) p. 480: '[Es] bilden sich in einer ständigen Praxis allmählich Übereinstimmungen heraus, die erkennen lassen, dass es hier in der Fallentscheidung immer wiederkehrende Wertungs- und Beurteilungsgefüge gibt, die eine typisierende Betrachtung erlauben und es infolgedessen ermöglichen, den Raum der Generalklauseln in rechtliche Ordnungsbereiche zu gliedern. Im Zusammenwirken mit der dogmatisierenden Wissenschaft gelingt es dann, die zunächst vollkommene Unbestimmtheit der Klauseln durch Herausbildung von "Rechtsgedanken" zu überwinden und ihnen weitgehend die Form begrifflich-dogmatisch gefestigter "Grundsätze” zu geben. Auf diese Weise werden die Räume der Generalklauseln, die ursprünglich jeder Positivierung entbehren und infolgedessen auf der Landkarte der Kodifikationen als weisse Flächen erscheinen, zu einem Gebiet gegliederten positiven Rechtsstoffs, in dem tragende Rechtsgedanken verfestigt sind.' The present writer has elsewhere presented these ideas of Henkel in the following words: 'Comme H. Henkel l'a bien montré, de nombreux principes de droit sont issu d'une consolidation normative de standards juridiques. Sur la base de l'ordonnancement de la pratique issue de standards en des catégories constituées par un ensemble d'éléments typiques (Fallgruppen), émergent parfois des concepts ou idées juridiques plus généraux (Rechtsgedanken). Ils tendent à s'affermir, puis à s'affirmer. Par la définition progressive de leurs conditions d'application, par la différenciation des régimes qui tendent à créer un sentiment d'ordre, par le travail de la science du droit qui cherche à en 


\subsection{General principles as 'norm-sources'}

The generality of the principles puts them beyond the realm of operation or simple rules. On the one hand, their legal content is not so narrow, it is not defined in an as precise way as it is in rules; but at the same time it is not so broad as general political concepts or words used in the social fashion of a given moment. Therefore, the principles can play a middle role between the lex lata and the lex ferenda, being wholly neither the one, nor the other. They have that just degree of abstraction and concreteness, to be able to be dynamic and filled with some specific legal meaning at once. Principles live on that double polarity: (1) generality and flexibility on the one hand, and thus the capacity for serving as ground in a dynamic interpretation and in substantive development of the law, especially since the class of cases they can cover is not closed up; (2) anchoredness in the realm of legal phenomena, with a definable coremeaning and a overlookable system of extensions, which gives to the principles a genetic code able to grant that minimum of certainty without which the law opens up to the arbitrary.

If one follows what has been said, it appears that 'principles' are neither simple 'rules' nor simple 'vague ideas'. In any event, they play a prominent role in the creation of the law, and that function was perceived, in the definitions given at the outset, as being the proper meaning of the term 'source'. Consequently, one could envision principles of law, especially the great principles, filled with normative energy, as constituting a middle-ground category: they are 'norm-sources'. That is to say that they are not simple rules, where the element of application prevails quite neatly, nor simple 'legal ideas', where the legislative element outweighs outrageously, but they are a combination of both. Their specific role in the formative stage of new rules (at the legislative level) and their dynamic function in the application of the law indeed permits to look at them as a type of source of law which goes far beyond the idea of subsidiary filling of lacunae, as upheld at the time of the drafting of the Statute of the PCIJ, Article 38, letter 1, c (or para. 3, as it then was). Each single one of these great principles is thus in itself (and not only in the category 'general principles of law') a type of source of the law, a 'norm-source': it does not essentially deal with the fixed meaning of rules to be applied, but with the adaptation of the rules to some constitutional necessities, to new developments and needs, to conformity with basic value-ideas and namely to justice, and so on. General principles concern first of all legal dynamics. Their function is constitutional, and not administrative; and that very fact endows them with some element of source-power.

dégager le contenu juridique, finissent par se dégager des linéaments normatifs capables de se condenser en principes (Grundsätze). Le courant descendant du standard vers les faits de la vie finit ainsi par nourrir un contre-courant ascendant vers les concepts normatifs' (in 32 RBDI (1999) p. 433, fn. 165). 
The described power works in practice by way of successive 'accretions' (inductive) and 'concretization' (deductive) to which the principle leans itself. For example: the principle of good faith has been enlarged from the simple idea of bindingness of the own agreed word (pacta sunt servanda and fides cum hostis servanda est) towards the idea that all legitimate expectations, relevant in a legal relationship, should be protected (inductive accretion to the principle). On the other hand, when in 1974 the International Court was faced with the necessity to argue the binding nature of unilateral declarations, it found support in that idea of legitimate expectations, since it had recourse to the principle of good faith in its famous paragraph 46 at page 268 (deductive reasoning from the principle). ${ }^{24}$

Consider, further, for example, the jurisprudence on maritime delimitations. ${ }^{25}$ For a long time, since the North Sea Continental Shelf cases (1969), ${ }^{26}$ the International Court of Justice derived the specific rules to be applied from the very general legal idea of 'equitable principles'. That idea was said to be found in customary international law, and indeed to form its only material content. Thus, the whole question was regulated and permeated by equity, or, more precisely, by the principle of equity. If that point of departure is taken, one must then seek for equitable methods of delimitation and to consider the equitableness of the results reached; and moreover, to ask oneself as to the precise relationship between the equitable methods and the equitable result: does the last flow automatically out of equitable methods or is it a supplementary test? Is a result reached by equitable methods by definition equitable, or can such a result still be inequitable in a specific case because of a spontaneous feeling of justice? And in such a case, must the method be respected (with its grant of legal certainty) or can the equitable result (in a case-by-case approach) prevail? The Court, in fact, developed during many years a whole body of case-law on all these questions, and it had recourse to a wealth of rules it deduced more or less directly from the general idea of equity. Thus, the whole doctrine of maritime proportionality, i.e., that there must be some reasonable proportion between the lengths of the relevant coastlines and the area of shelf finally allotted, was developed under that heading. As all specialists know, the notion of maritime proportionality then went into considerable complexities. Now, the point inter-

24. ICJ Reports (1974) p. 268, para. 46: 'One of the basic principles governing the creation and performance of legal obligations, whatever their source, is the principle of good faith. Trust and confidence are inherent in international co-operation, in particular in an age when this co-operation in many fields is becoming increasingly essential. Just as the very rule of pacta sunt servanda in the law of treaties is based on good faith, so also is the binding character of an international obligation assumed by unilateral declaration. Thus interested States may take cognizance of unilateral declarations and place confidence in them, and are entitled to require that the obligation thus created be respected.'

25. See R. Kolb, Case Law on Equitable Maritime Delimitation, Digest and Commentaries (The Hague, Nijhoff 2003).

26. ICJ Reports (1969) pp. 3 et seq. 
esting us here is the impossibility, by any stretch of imagination, to consider that the Court, in doing what it did, did in fact obey to the classical dogma of positivism, and only applied the law as it stood. It is obvious in this field more than in others, that the Court has in effect developed the law, or to say it more bluntly: that it legislated. And this legislation took place under the auspices of a general principle, 'equity', or 'equitable principles'. Thus, in other words, the principle of 'equity' served here as source of the law. But it was a source which was not determined (except in the highest stages) by the formal legislator; it was a source for the judge, for an ancillary legislation which in the field under consideration has been particularly strong and prominent.

\subsection{Sources of law/of obligation}

A further distinction may be useful for a better understanding of the work of the general principles of law, of which good faith is one of the most prominent representatives. This distinction is that between 'sources of law' and 'sources of obligation'. ${ }^{27}$ The first source is said to give rise to objective rules of law, valid erga omnes: e.g., a piece of legislation in the municipal legal systems. Conversely, the second is said to be more limited and to touch only upon subjective entitlements of the different legal persons: e.g., the creation of a contractual right to obtain a good. In the municipal sphere, this distinction is quite clear-cut: there is a legislator for the enactment of the general and objective sources of law; and there are the different legal persons who, in the field of their personal autonomy, create various and differing legal relations which govern only their personal situation.

In the field of international law, the two aspects merge into one another. If the distinction is not abolished, it is certainly not clear-cut. The reason is straightforward: in international law, there is no centralized legislator; it is the subjects of law themselves who in a continuous process of interaction create the legal bonds. Thus, there can be no neat separation between objective law and subjective entitlements, between the level of community and of individuality, between utilitas publica and singulorum. Consider, for example, the situation prevailing through a local or bilateral custom. This is as much a source of law, albeit limited ratione personae and loci, as it can be seen as a mere source of obligation between some states only. Conversely, a unilateral act will normally be a source of obligation for the state performing it, even if the adherence by

27. On possible implications of this distinction, see, e.g., G.G. Fitzmaurice, 'Some Problems Regarding the Formal Sources of International Law', in F.M. van Asbeck, et al., eds., Symbolae Verzijl: présentées au professeur J.H.W. Verzijl à l'occasion de son LXX-ième anniversaire (The Hague, Nijhoff 1958) pp. 153 et seq. and the critique of M.H. Mendelson, 'Are Treaties merely a Source of Obligation?', in W.E. Butler, ed., Perestroika and International Law (Dordrecht, Nijhoff 1990) pp. 81 et seq. 
other states can elevate such a declaration to a somewhat harder and more general source of law.

How are the 'norm-sources', i.e., the general principles of law to be placed within that distinction? Are they mainly sources of law or sources of obligation? The answer is that they can be both. A general principle of law can, by way of accretion, as described above, enrich itself and generate thereby a new sub-principle, which will be of general application. It here displays the role of a source of (objective) law. For example, the principle of good faith came at a certain moment, during the middle ages, to encompass the newly developed rule against abuse of rights (aemulatio). It thereby incorporated a new rule or principle of binding character, and it did so outside of a specific single case. The same happened at the level of international law in the twentieth century, when the rule against abuse of rights penetrated the international legal system.

But a general principle will often operate as a source of obligation. It thereby remains a source, especially since in international law, as explained, the two domains are not neatly separated. Thus, for example, where the principle of good faith (as embodying the idea of legitimate expectation) creates a binding obligation on a party in consequence of his prolonged silence, this course having created a legitimate confidence in the status quo as being final, the principle operates as a source of obligation. A good example for this is furnished by the Temple of Preah Vihear case (1962). In this case, the International Court of Justice was faced with a plea that an established boundary had to be discarded since it had been drawn by error and in disobedience to the principles enshrined for that purpose in the governing treaty of 1904. The Court replied that the conduct of the interested states, having for a prolonged time acquiesced in that boundary in full knowledge of its course, precludes the Siam authorities from challenging it at present. The Court here applied in conjunction the principles of acquiescence (qui tacet consentire videtur si loqui potuisset ac debuisset) and of estoppel. It did so in order to protect the finality of the boundary - boundaries, it is known, are very sensitive matters, and international law does not allow them to be changed unilaterally - and also the legitimate expectation created by the long silence, accompanied by a parallel day-to-day acceptance of the boundary in the Temple area. ${ }^{28}$ Thus, by operation of these principles, derived from the more general one of good faith (protection of legitimate expectations), the Court found that the subjective rights of the parties had changed: Siam had lost a right to demand a revision of the boundary and Cambodia had acquired a corresponding right to claim the finality of that boundary. The principle of good

28. ICJ Reports (1962) pp. 6 et seq., 22 et seq. On this jurisprudence, see R. Kolb, La bonne foi en droit international public (Paris, Presses Universitaires de France 2000) pp. 339 et seq. For a critique on the application of these Western, and quite elaborated, legal concepts in the context of Asiatic powers, see P.C. Jessup, The Price of International Justice (New York, Columbia University Press 1971) pp. 15 et seq. 
faith, through acquiescence and estoppel, has thus operated in this context as a source of obligation.

In both ways, as a source of law or of obligation, general principles may display a powerful creative and regulative activity.

\section{CONCEPT AND APPLICATIONS OF GOOD FAITH ${ }^{29}$}

\section{$2.1 \quad$ Three concepts of good faith ${ }^{30}$}

General notions such as good faith cannot be entirely grasped by abstract definitions. It is rather necessary to split up their meaning in various aspects gathered

29. In order not to exceed in length, there will be no extensive quotations or references in the following passages devoted to good faith. The reader can refer to the literature indicated in the next footnote, and as to my own views to my three opuses indicated there.

30. On good faith in international law, see L. Cavaré, La notion de bonne foi et quelques-unes de ses applications en droit international public, Cours de l'Institut de Hautes Etudes Internationales, Paris 1963/1964; B. Cheng, General Principles of Law - As Applied by International Courts and Tribunals (London, Stevens and Sons 1953) pp. 105-160; J.P. Cot, La bonne foi en droit international public, Cours de l'Institut de Hautes Etudes Internationales, Paris 1968/1969; Kolb, op. cit. n. 28; J.P. Müller, Vertrauensschutz im Völkerrecht (Cologne, Carl Heymanns Verlag 1971); J.F. O'Connor, Good Faith in International Law (Aldershot, Dartmouth 1991); R. Yakemtchouk, La bonne foi dans la conduite internationale des Etats (Paris, Editions Techniques et Economiques 2002); E. Zoller, La bonne foi en droit international public (Paris, Pedone 1977). As to articles, see in particular, A. D'Amato, 'Good Faith', in R. Bernhardt, ed., Encyclopedia of Public International Law (hereinafter: EPIL), Vol. 7 (Amsterdam, North-Holland 1984) pp. 107-109; M. Byers, Custom, Power and the Power of Rules (Cambridge, Cambridge University Press 1999) pp. 106-126; F.A. von der Heydte, 'Die bona fides und die einzelne Rechtsnorm', 11 Österreichische Zeitschrift für öffentliches Recht (1961) pp. 364-374; R. Kolb, 'La bonne foi en droit international public', 31 RBDI (1998) pp. 661-732; R. Kolb, 'Aperçus sur la bonne foi en droit international public', 54 RHDI (2001) pp. 1-42 and pp. 383-428; M. Lachs, 'Some Thoughts on the Role of Good Faith in International Relations', in R.J. Akkerman, et al., eds., Declaration on Principles: A Quest for Universal Peace, Mélanges B.V.A. Röling (Leiden, Sijthoff 1977) pp. 47-55; J.M. Mössner, 'Vertrauen als Prinzip der Völkerrechtsordnung', Politik und Kultur, (1979) no. 3, p. 56-66; J.M. Mössner, 'Vertrauen in der internationalen Politik: Völkerrechtliche Aspekte', in B. Simma and E. Blenk-Knocke, eds., Zwischen Intervention und Zusammenarbeit (Berlin, Duncker \& Humblot 1979) pp. 245-297; J.P. Müller and R. Kolb, 'Article $2 \S 2$ of the Charter', in B. Simma, ed., The Charter of the United Nations: A Commentary, 2nd edn. (Oxford, Oxford University Press 2002) pp. 91-101; V. Paul, 'The Abuse of Rights and Bona Fides in International Law', 28 Oesterreichische Zeitschrift für öffentliches Recht (1977) pp. 107-130; G. Schwarzenberger, 'The Fundamental Principles of International Law', 87 Recueil des cours (1955-I) pp. 290-326; G. Sperduti, 'Il principio della buona fede e l'ammissione di nuovi membri nelle Nazioni Unite', 7 Comunità internazionale (1952) pp. 42-62; A.M. Stuyt, 'Good and Bad Faith', 28 NILR (1981) pp. 54-58; H. Thirlway, 'The Law and Procedure of the International Court of Justice (1960-1989): General Principles and Sources of Law', 60 BYIL (1989) pp. 7-49; A. Verdross, 'Bona Fides', in K. Strupp and H.J. Schlochauer, eds., Wörterbuch des Völkerrechts, Vol. I (Berlin, De Gruyter 1960) pp. 223-224; A. Verdross, 'La bonne foi comme fondement du droit international public', 5 Revue hellénique de droit international (1952) 
from a review of the practice. This is even more necessary for a concept which is rooted in the roman and civil law tradition, and which has not always been easily understood by Anglo-Saxon lawyers. ${ }^{31}$ If such a review of practice is made, it appears that good faith is invoked in three rather different settings and functions. Moreover, these concepts have little to do which each other.

\subsubsection{Good faith in a subjective sense}

Very often, especially by French lawyers, good faith is thought to be nothing more than a psychological concept, making reference to some sort of inner knowledge and correctness. Good faith here seems to be a properly moral concept, searching to introduce into the law a measure of rectitude, correctness, fair dealing, honest belief, absence of malice. In this sense, good faith is a state of mind and of inner spirit. ${ }^{32}$ This sense was, if not engrafted, so at least furthered, within the roman law tradition by the canon law of the middle ages, which gave a deliberately subjective bent to the concept of good faith in order to further its moral content. ${ }^{33}$ It is sometimes claimed that the law cannot or ought not to be concerned with such inner states of mind. However, this is not necessarily true: it is sufficient to think of criminal law. What is true, is that

pp. 17-21; A. Verdross, 'Die bona fides als Grundlage des Völkerrechts', in D.S. Constantopoulos and H. Wehberg, eds., Gegenwartsprobleme des internationalen Rechtes und der Rechtsphilosophie: Festschrift für Rudolf Laun zu seinem siebzigsten Geburtstag (Hamburg, Girardet 1953) pp. 29-33; G. White, 'The Principle of Good Faith', in V. Lowe and C. Warbrick, The United Nations and the Principles of International Law, Essays in Honour of Michael Akehurst (London, Routledge 1994) pp. 230-255; E. Zoller, 'La bonne foi en droit international public', in Travaux de l'Association H. Capitant, tome 43: La bonne foi (Paris, Litec 1994) pp. 569-582. On the rule of legitimate expectations in WTO-law, see, e.g., T. Cottier and K.N. Schefer, 'Good Faith and the Protection of Legitimate Expectations in the WTO', in M. Bronckers and R. Quick, eds., New Directions in International Economic Law: Essays in Honour of John H. Jackson (The Hague, Kluwer Law International 2000) pp. 47-68. See also, in general, H. Eichler, Die Rechtslehre vom Vertrauen (Tübingen, Mohr 1950); F. Gorphe, Le principe de la bonne foi (Paris, Dalloz 1928); A. Volansky, Essai d'une définition expressive du droit basée sur l'idée de la bonne foi (Paris, Librairie de jurisprudence ancienne et moderne 1930); P. Widmer and B. Cottier, eds., Abus de droit et bonne foi (Fribourg, Editions Universitaires Fribourg 1994).

31. As to this last point, see, e.g., the speeches of the US representative at the San Francisco Conference, when the Charter of the United Nations was drafted: Documents of the United Nations Conference on International Organization, San Francisco, 1945, Vol. 6 (London, United Nations Information Organizations 1945), p. 74: 'I should like to say that we have been convinced by the arguments of our friends and are now eager to support this amendment. We had not realized exactly what the words meant to those who have lived and worked in the great tradition of the Roman law. We had thought they were quite unnecessary ... But now we realize that this is a customary phrase, which ... conveys the meaning that we are all to observe those obligations, not merely the letter of them, but the spirit of them ...'

32. See also Black's Law Dictionary, 5th edn. (St. Paul, Minn., West Publishing Co. 1979) p. 160 .

33. See L. Scavo Lombardo, Il concetto di buona fede nel diritto canonico (Rome, Libreria dell'Università 1944). 
good faith in this subjective sense plays only a quite remote role in international law, a law dealing with sovereign states. In this field of law, good faith in the subjective sense has mainly concentrated on one specific aspect, the others being neglected. This aspect is known also in the municipal legal systems. The question is about the fate of a juridical act that is vitiated by a fact of which one of the parties ignores the existence. Should the act then be considered valid, notwithstanding its default, and this by virtue of the ignorance of this default by the party now aggrieved? Is his 'good faith' (absence of knowledge) to be protected? One example is the following: $\mathrm{X}$ buys a collection of books of international law from somebody whom he thinks the owner of these books; but in fact, the seller is a thief, who got these books by a burglary. In legal terms, it is said that $\mathrm{X}$ is of good faith; he ignored the thief and believed that the seller was the owner. This inner belief (or ignorance) is a fact; and it has to be proven as any other fact. If it is proven, some legal orders provide a protection for the innocently ignorant buyer. The aim of this protection is twofold: first, to give some relief to the innocent who otherwise would be deprived of his goods, having to return them to the real owner, without being sure to get back his money; second, in a more general reasoning because of the general necessity of legal certainty and protection of legitimate expectations, lest commerce and exchanges are to be excessively hampered.

This type of good faith can thus be described in more general terms as follows: in the most narrow sense, good faith expresses a state of mind consisting in a false representation of legally relevant facts and which manifests itself in the ignorance of some defect of these facts with respect to the legal norm whose application is claimed.

In international law, this type of subjective good faith finds some applications, but they are neither very numerous nor very prominent. International law does not attach great weight to the state of mind of sovereign states and it only seldom requires inquiring into it. ${ }^{34}$ Applications ${ }^{35}$ of such a good faith are to be found in the field of acquisition of territory (acquisitive prescription); $;^{36}$ of temperaments to the full effects of voidness; of non-application of certain rules of internal law whose existence was legitimately ignored; of mitigating certain consequences of responsibility (and especially in the compounding of the sum of damages awarded); in some cases of denial of justice (subjective bad faith); or else in some aspects of abuse of rights (intention to harm somebody).

As has been said, subjective good faith is a fact, which is presumed and the

34. As to this point, see Zoller, op. cit. n. 30. The error of this author, in our eyes, is to have confined good faith to this subjective aspect, and to have ignored the other ones.

35. See Kolb, op. cit. n. 28, at pp. 117 et seq.

36. It is not that international law requires subjective good faith in order to acquire the territory; it is rather that subjective good faith influences the interpretation of the titles and can bring to the conclusion that, if existent, the conditions for prescription are easier fulfilled, e.g., as to the required time-span. See Kolb, op. cit. n. 28, at pp. 416 et seq. 
non-existence of which has to be proved. ${ }^{37}$ Thus, this good faith is not a norm in any sense of the word. It has no normativity. It therefore is no source of law at all, but just a factual element of a norm to the existence of which this norm attaches certain specified consequences. As such, it need not interest us any further.

\subsubsection{Good faith in the sense of an open-ended legal standard}

As the law cannot operate only with specific and rigid concepts, but rather needs some general terms in order to keep the flexibility enabling it to apply to the milliards of cases eventually falling in its reach, it has to insert in its norms some vague notions, such as 'due regard', 'reasonable time', or indeed 'legitimate expectation'. These general concepts are called legal 'standards'. Sometimes, these standards are engrafted upon a general principle or a specific norm; its aim is then to aid to a better application of the norm to the many different cases which may arise under it. The standard is in these cases ancillary, in that it operates only in conjunction with the norm or principle at stake. Thus, it is sometimes claimed that an extraterritorial jurisdiction can be lawfully exercised only if there is a bona fide-link to the subject matter. In such cases, the term good faith has no proper meaning; it could without altering the legal situation be replaced by the word 'reasonable link'. And reasonableness, in turn, asks from the law-applier to weigh up a series of contextual aspects: teleological aspects (policy reasons), efficacy, reasons of the rule and nature of things, equity intra legem, effet utile, practicability, consideration of the consequences of a course taken, etc.

However, sometimes, such a standard can also be used autonomously, i.e., without being the satellite of a norm or principle. Such has been the case in some commercial law special agreements, submitting to arbitration disputes of expropriation: it was there sometimes conceded that the arbitrator should apply, as applicable law, concepts such as equity, as goodwill or as good faith. ${ }^{38}$ In such cases, this is nothing more than a renvoi to the discretion of the arbitrator to act ex aequo et bono and according to universal principles of law.

As a source, good faith displays a different role in the case of the two roles described above, namely the ancillary and the autonomous.

In the ancillary cases, its meaning is aligned to that of reasonableness. Therefore, it plays the role of a powerful standard, helping to the application in particular cases of norms in themselves too abstract to be able to espouse all the multifaceted features of the single cases. But this role does not make a source of law out of it. The role of good faith (reasonableness) is here limited to be a

37. See Kolb, op. cit. n. 28, at pp. 124 et seq.

38. See, e.g., the Sapphire International Petroleum case (1963), 19 Annuaire suisse de droit international (1962) pp. 273 et seq. The applicable law was 'les principes de la bonne foi et de la bonne volonté ...'. 
catalyst between the facts and the norm. The norm is too general for a series of specific cases; thus, a concept is introduced to bridge this gap; this concept helps to better translate the facts into the law. This is what is properly called a legal standard. One sees the difference with a source properly so called: the source is put on the plane of the creation of new norms or at least of the development of the law (which is the creation of an enlarged, and in that sense, new norm). Conversely, the standard has its regulative role not on the level of the norm, but in between the norm and the facts. A source concerns the relationship norm/norm; a standard touches upon the relationship norm/facts.

As to the autonomous role of some standards, it here condenses to a true source of law. It is not any more the case to look for a catalyst to the facts, but to use the standard as a means to create ad hoc and for the single case, modo legislatoris, the rules to be applied, and in fact to apply them. This exercise is performed under the general guise of an equitable function and with the constraint to reach an equitable result for the individual case. Reaching an equitable result certainly means reaching an equilibrated result, in which all factors, also extra-legal ones, have been balanced up. This function is often to be found in commercial (concessions, expropriation) contracts. ${ }^{39}$ The source-function is here performed in a realm of maximum freedom: it is not the question of merely developing the law or of creating new subjective entitlements, but to provide the basis for a completely new legal construction.

\subsubsection{Good faith as a general principle of law}

Finally, good faith has an objective sense: it is here a powerful general norm, a general principle of law. This is by far the most important form in which good faith appears in international law. The substance of good faith as a general principle decomposes itself in several more concrete aspects. ${ }^{40}$ There are three main aspects, presented here in order of decreasing importance.

First, the principle of good faith requires the protection of legitimate expectations which a certain course of conduct has provoked in another person, whichever the real (but unexpressed) intent of the actor. This sense is an abstraction operated in the nineteenth and in the twentieth century from the original sense of good faith, i.e., the faithfulness to the deed undertaken. It is an abstraction in the sense that it grasped the ratio of the original rule and enlarged it in order to fit the conditions of modern society, with its much denser and

39. For the practice, see, e.g., E. Paasivirta, Participation of States in International Contracts (Helsinki, Lakimiesliiton Kustannus 1990) pp. 59 et seq.; P. Weil, 'Principes généraux du droit et contrats d'Etat', in P. Fouchart, et al., Le Droit des Relations Economiques Internationales: Etudes Offertes à Berthold Goldman (Paris, Litec 1982) pp. 387 et seq.

40. For a fuller account of these aspects, see Kolb, op. cit. n. 28, at pp. 143 et seq., 179 et seq. 
complex relationships, and the thus increased necessity to provide for legal certainty and stability.

Second, on the negative side of the coin, good faith as a general principle protects certain finalities anchored in the common interest against excessive individualist pretenses (prohibition of abuse of rights, trespass). Moreover, the principle also protects the object and purpose of a transaction against all acts intending or having the effect of depriving it of its use (e.g., Art. 18 of the Vienna Convention of Treaties; bindingness of provisional measures in judicial proceedings when necessary to preserve the outcome on the merits; action against the object and purpose of the treaty as considered by the International Court in the Nicaragua case, ${ }^{41}$ etc.).

Third, the principle of good faith has coagulated in it certain prohibitions of non loyal conduct, especially through the old maxim, furthered by the civilists and canonists of the middle ages, that nobody can take advantage of his own wrong (nemo ex propria turpitudine commodum capere potest). This maxim has had a series of applications in international law, and it has often been linked with the more general principle of good faith. ${ }^{42}$

In any of these three concepts of the principle, good faith shows to be based on the idea of social solidarity. Its aim is to blunt the excessively sharp consequences sovereignty and its surrogates (e.g., the principle of consent, no obligation without consent) may have in the international society, in everincreasing need of cooperation. ${ }^{43}$ Thus, for example, good faith, on the basis of

41. ICJ Reports (1986) pp. 135 et seq. See on the point Kolb, op. cit. n. 28, at pp. 283 et seq.

42. See R. Kolb, 'La maxime "nemo ex propria turpitudine commodum capere potest" (nul ne peut profiter de son propre tort) en droit international public', 33 RBDI (2000) pp. 84-136.

43. As the present writer explained elsewhere: 'Entre toutes les fonctions si importantes du principe de la bonne foi, son essence la plus intime réside dans l'affirmation du côté relationnel $d u$ droit. Toute action juridique est projetée vers l'extérieur car elle vise à affecter les intérêts et en général la position que le droit reconnaît à autrui. En d'autres termes, le droit régit toujours un rapport social. Les principes du volontarisme ou de l'autonomie de la volonté, ancrés pour le droit international dans la notion de souveraineté, ne considèrent que la sphère du sujet qui agit: l'obligation n'est censée naître que de sa volonté. Un tel parti, pensé à bout, mène à la destruction de la règle de droit. Il ramène à la catégorie des devoirs contre soi-même, c'est-à-dire à la morale. Ce n'est pas un hasard si les positivistes les plus imbus de la notion de souveraineté ont parlé du droit international comme d'une moralité positive. Le principe de bonne foi vise à rééquilibrer ce rapport qui préside à la création, à la mise en oeuvre, à la modification et à la terminaison de la règle de droit ou de l'obligation. Il commande de tenir compte de la confiance légitime et des finalités objectives d'un rapport considéré sub specie alteritatis. Il rattache à cette extériorité des effets de droit indépendants de la volonté réelle, mais inintelligible, d'un sujet. La bonne foi est donc une notion solidariste particulièrement importante en droit international précisément parce que le volontarisme individualiste a cherché si longtemps à défendre une place exagérée, incompatible avec la notion même d'un droit objectif dans les relations internationales. La volonté est dans son rôle quand elle explique une grande partie de la formation du droit positif. Elle est facteur de progrès quand elle permet une analyse nuancée des faits sociaux et quand elle permet à la liberté de s'exercer en droit. 
the doctrine of legitimate expectations, will have the effect of producing new obligations for the parties even outside the formal consent of both, simply by virtue of a legal qualification of their conduct in the light of the social need of legal certainty and stability. Examples of this will be provided in due course. For the moment, it may be useful to note that this objective good faith plays in the first place the role of a powerful source of obligations, attaching ex lege certain consequences to certain courses of conduct.

The mode of operation of good faith as a general principle of law is not confined to the very general legal ideas just mentioned. If it were, it would indeed remain too abstract. In effect, the principle does not only seek to operate along the legal ideas spelled out, if one may say, directly, by putting them to application without any intermediary to the specific cases. It rather also seeks to 'concretize' its legal contents by reversing them into a series of intermediary principles, more concrete in nature, and fitting to the several fields of law where the general idea of the principle is likely to be put at stake. The role of the principle is here to nourish with legal substance and to reduce to a certain unity a series of coordinated legal rules and principles, which in a certain sense are its vassals. For the principle of good faith, we may quote the following concretizations:

- The pre-contractual obligations (Art. 18 of the Vienna Convention on the Law of Treaties).

- The prohibition to deprive a transaction of its objects and purpose.

- The primacy of the spirit over the letter in the interpretation of legal texts.

- The binding nature of normative unilateral acts of states.

- The doctrine of normative acquiescence (estoppel by silence; qui tacet consentire vedetur si loqui potuisset ac debuisset).

- Estoppel.

- The responsibility for appearances created (responsabilité pour apparence, Vertrauenshaftung).

- The prohibition of abuse of rights including détournement de pouvoir and fraud to the law.

Elle excède sa place quand elle cherche seule à jouer un rôle constitutif dans la création et la modification des situations juridiques ou quand elle s'assigne le rôle de fondement unique du droit tout entier. En plaçant le sujet (l'Etat) au dessus du droit, en laissant à la puissance et à l'entreprise uti singuli les innombrables interstices entre les expressions ponctuelles de volonté, ce volontarisme aboutit invariablement au dépérissement ou à l'affaiblissement de la règle de droit. En réintroduisant l'idée de bilatéralité et donc l'idée de l'autre, la bonne foi se dévoile être le frère jumeau de l'idée du droit dans les relations internationales (comme la souveraineté l'est pour la volonté). Bonne foi et droit international relèvent d'une communauté de destin: l'affaiblissement de l'une est liée au déclin de l'autre. D'où le sens profond de ces mots si apocalyptiques de C. Van Bynkershoek: "Hanc si tollis [bona fides], tollis mutua inter Principes commercia ... et tollis ipsum ius gentium" [footnotes omitted; RK].' See Kolb 2001, loc. cit. n. 30 , at pp. $427-428$. 
- The doctrine of reasonable time, e.g., for denouncing a legal act.

- The maxim that nobody can profit from its own wrong.

- Perfidy in the law of warfare.

- The doctrine of Critical Date in the law of territorial delimitation (no selfserving acts made after the critical date can be invoked to your benefit).

- Etc. ${ }^{44}$

As it can be seen, it is impossible to get hold of the principle in the majestic immobility of its abstraction. It is mainly as value, attempting to expand its legal substance throughout the legal system by means of derived norms and principles, that one can grasp the real operation of the great principles of law. It appears from the practice that the principle of good faith is one of the principles most powerful and most rich of normative substance, able to be concretized in ever-new contexts. In one word: the key to the life of the great principles is the concept of 'concretization', which has not received yet the attention it deserves.

\subsection{Judicial practice for good faith as a principle of law}

At this juncture, some examples of the operation of good faith as a general principle may be useful.

\subsubsection{Good faith as principle protecting legitimate expectations}

In many cases, the principle of good faith operates in protecting the legitimate expectations which a legal-factual relationship among two or more subjects has generated. This legitimate expectations doctrine is not entirely new. It was known and was applied already in the twentieth century jurisprudence, by arbitral tribunals. Thus, in the Port of Portendick case (1843), the French minister of maritime and colonial affairs had informed the British ambassador in Paris that the French government had no intention whatsoever to close down the port of Portendick, under French control, situated in the territory of today's Senegal. Some months after this statement, after some local riots, the French in effect blockaded the port. Some British ships sailing towards that port, and not informed of the closing down of it, suffered losses in consequence of the new situation. The arbitral tribunal constituted to hear this case started by confirming that the French government had kept the sovereign right to close down the port, the more so in order to respond to riots which had broken out (these riots had been foreseeable). The point, however, was that the French authorities had not notified that measure to the British authorities. It is only on that point that a claim was brought by the United Kingdom. According to the tribunal, such a notification was all the more necessary in the light of the previous assurances

44. For the practice, see Kolb, op. cit. n. 28, at pp. 179 et seq. 
given to the effect that the port would be kept open. The arbitrator condemned France on that ground, by founding his finding on the 'trust and confidence that a state may reasonably place in the word of another'. ${ }^{45}$ Thus, the decision at issue was resolved by operation of the principle of good faith, in the sense of the protection of legitimate expectations, which a subject freely created, and of which he must thus respond. ${ }^{46}$ As can be seen, in this case, the principle of good faith performed the classical role of a source of obligation: there was a freedom of the French authorities to act as they saw fit in the first place; there came a course of conduct (the assurances given) which altered the legal relationship among the parties; and finally, because of the principle of good faith, the French authorities were submitted to a new obligation and the British acquired a new subjective right.

In the Norwegian Fisheries case (1951), the International Court of Justice had to deal with a contested system of maritime limits. In 1935, the Norwegian government passed a decree (which was the last in a series of decrees) by which it delimited the maritime areas towards the high seas. Having regard to the very irregular and tormented coastline and to the existence of a fringe of islands, the decree proposed a system of straight baselines, which seemed to some extent derogatory from the general practice of states under the law of the sea. It was the validity of that system of drawing baselines which was in dispute. This was so because by these straight lines the waters under Norwegian sovereignty were extended towards the sea, to the detriment of some British fisherman who had for some time (with interruption) fished in those waters. The Court reasoned as follows. The Norwegian lines were enforced on a regular basis without being contested by the states interested in the status of the waters of the relevant area. Apart from a note asking for explanations issued by the French government, 'this system was consistently applied by Norwegian authorities and ... it encountered no opposition on the part of other States'. ${ }^{47}$ As to the United Kingdom, it knew of the existence of this system and of the way it was enforced. Yet, 'for a period of more than sixty years the United Kingdom Government itself in no way contested it'. ${ }^{48}$ Whence the consequence is drawn that the United Kingdom cannot any more contest that system in its application to it, since there has been, on the part of the United Kingdom government, acquiescence by inaction: 'The notoriety of the facts, the general toleration of the international community, Great Britain's ... prolonged abstention would in any case warrant Norway's enforcement of her system against the United Kingdom.' In short terms: he who is silent when knowing, and when his interests are affected, is taken to have accepted (is treated as having accepted); qui

45. See Cheng, op cit. n. 30, at pp. 138-139.

46. See A. de la Pradelle and N. Politis, Recueil des arbitrages internationaux, Vol. I (17981855) (Paris, Editions internationales 1957) pp. 512 et seq.

47. ICJ Reports (1951) pp. 136-137.

48. Ibid., at p. 138. 
tacet consentire videtur, si loqui potuisset ac debuisset. This acquiescence ${ }^{49}$ is directly imputed by virtue of the operation of a legal norm; it is not here a question of real consent, of will. Rather, the general principle of good faith, in asking that legitimate expectations created be respected for reasons of equity and of legal security, compels to consider that in such context the position of the state having remained passive is such as if he had consented to the acts at issue. It is easy to see here again that the principle operates as a source of obligations. By virtue of the principle, through the doctrine of normative acquiescence, which is one of its provinces, the subjective positions of the parties to the dispute were altered: a new right was born on one side, and a new equivalent obligation was burdened on the other party at the same time.

It may be useful here to give a last classical example, that of the Arbitral Award made by the King of Spain on 23 December 1906 (1960), a case decided by the International Court of Justice. The dispute was about the validity of an arbitral award the King of Spain had rendered in 1906 in the context of a territorial litigation between Honduras and Nicaragua. The award had on the balance been slightly more favourable to Honduras. Nevertheless, and according to its legal obligation to respect the award rendered, Nicaragua immediately felicitated its counterpart, expressing its appreciation to see this old dispute finally solved and put aside. Further, two days after the issuing of the award, Nicaragua's government expressed its gratitude to the King of Spain for having thus settled the dispute. Other acts displaying an implicit acceptance of the award followed. ${ }^{50}$ However, in 1912, after a change of government, i.e., six years after the issuing of the award, Nicaragua contested the validity of the award. It invoked two reasons for voidness of the award. First, that the designation and the jurisdiction conferred to the arbitrator had been irregular, since the treaty providing the basis for the recourse to arbitration had by the relevant time already expired. Second, that the award was in excess of powers, contained essential errors, was not sufficiently motivated and suffered of contradictions and obscurities. ${ }^{51}$ According to Honduras, these allegations were inadmissible, since the previous conduct of Nicaragua amounted to acquiescence and founded an estoppel. ${ }^{52}$ The Court fully espoused this thesis: for it, Nicaragua had by its conduct fully endorsed the award and was not any more to be allowed to contest its validity at the present stage. ${ }^{53}$ In the words of the Court: 'In the judgment

49. On this doctrine of acquiescence, see Kolb, op. cit. n. 28, at pp. 339 et seq., with many further references.

50. ICJ Reports (1960) pp. 210-212.

51. Ibid., at pp. 205, 207, 214 et seq.

52. See ICJ Pleadings Series (1960-I) pp. 502 et seq.; (1960-II) pp. 37 et seq.

53. ICJ Reports (1960) pp. 209, 213. As it is said in the summary to the judgment on the internet site of the ICJ (<www.icj-cij.org $>$ ): 'Finally, the Court considered that, having regard to the fact that the designation of the King of Spain was freely agreed to by Nicaragua, that no objection was taken by Nicaragua to his jurisdiction, either on the ground of irregularity in his designation or on the ground that the Treaty had lapsed, and that Nicaragua had fully 
of the Court, Nicaragua, by express declaration and by conduct, recognized the Award as valid and it is no longer open to Nicaragua to go back upon that recognition and to challenge the validity of the Award. ${ }^{54}$

Once more, the usual mechanism of a source of obligation can be seen: good faith attached to a conduct the effect if modifying the subjective position of the parties, one with respect to the other. To a right acquired on one side corresponds a new equivalent obligation, which burdens the other side.

The Temple of Preah Vihear case (1962) has already been presented, albeit shortly. ${ }^{55}$ It is decided along the same lines, according to the same principles.

In the foregoing examples, the principle of good faith displays some features which do not differ from those that each norm presents. Indeed, each norm is a source of obligations; otherwise, it is not a norm, it not being able to alter the relative legal positions. But these examples show also the particularities of the principle of good faith-expectations in its law-creating function (source of obligations). The law-creating fact is not situated at the same level of the legal system. The rules operate at a more special level, whereas the principle is a more general and powerful source of obligations. This point needs some clarification.

A character of speciality characterizes the usual relationship between a norm and a set of facts: such particular norm attaches to such particular fact, as defined in the norm, such particular legal consequence. Example: if a ship sailing in the territorial waters of a state undertakes specific acts, as listed in Article 19 of the Law of the Sea Convention, which are to be considered acts incompatible with the duty of innocent passage, the coastal state may undertake the necessary steps to expel that ship from its waters. Or: if that person is a duly accredited diplomat, he enjoys the privilege of immunity, and hence he cannot be arrested for criminal prosecution. One sees that in this ordinary case the facts contemplated are precisely set out; and it is as such that they are understood to fall under the specific norm contemplating them.

However, in some cases, the relationship between the norm (principle) and the facts is different: it is not dominated by a character of speciality but rather by a character of generality. Certain general principles of law contemplate not a specific behaviour (non-innocent acts in the territorial sea, due accreditation, etc.), but any fact whatsoever emerging out of human conduct in order to attach to it, under certain conditions, a loss of some right on the one hand (preclusion) and the acquisition of a new right on the other. This is the case of estoppel and of normative acquiescence, as previously discussed. By their operation directed to a completely open-ended array of facts, they bring a certain basic value and

participated in the arbitral proceedings, it was no longer open to Nicaragua to rely on either of those contentions as furnishing a ground for the nullity of the Award.'

54. ICJ Reports (1960) p. 213.

55. For further comments on this case, see Kolb, op. cit. n. 28, at pp. 375-377, 381-382. 
practical unity throughout the legal system. And if such operation of all the general principles be cartographed, it would be possible to perceive the legal system under the perspective of a series of fundamental points of gravity, which constitute its very heart. In this sense, the general principles are general catalysts of the legal system: they are great bridges between the law and the facts, they reduce the eternal gap between both. They are thus a particularly powerful source of obligations. And herein precisely consist their essential role and their indispensable contribution.

\subsubsection{Good faith as prohibiting abuse of rights}

It is not possible at this juncture to discuss the rather complex principle of abuse of rights and abuse of discretion in international law. ${ }^{56} \mathrm{~A}$ single example of the application of the rule must suffice. In the Lalane Ledour case (1902), the chief of the customs office at Ciudad Bolivar had refused the shipping of meat cattle which L. Ledour wanted to expedite to French Guyana. The tribunal could establish that the true reason of that refusal was not linked to sanitary or other legitimate motives, but to an intervention of the President of Guyana, who wanted to avoid the shipping because of important private interests in an enterprise in direct concurrence with that of L. Ledour. The arbitrators hence concluded that there had been abuse of authority and held Guyana responsible. ${ }^{57}$

The operation of the principle of good faith - in this context good faithfinality - is to attach once more a shift in the legal entitlements of the subjects in interaction, and this again in consequence of a general set of facts, not defined in a closer way.

\subsubsection{Good faith as a source of legal development and of gap-filling}

A last example may be given, which shows us the principle of good faith in a slightly different role. In the Westland Helicopters case (1984), at the arbitration stage (ICC), the arbitrators were confronted with the question to what extent there is a subsidiary responsibility of member states in an international organization. If the organization is not able to live up with the consequences of its acts, if it has no proper means to pay damages, can the claimant sue the states which composed it, or must he stop at the level of the organization? The question had up to the 1980s not received many answers, because it hardly had ever arisen in practice. In the mentioned case, the arbitrators considered it outraging to free the states composing the Arab Organization for Industrialization from all subsidiary responsibility, especially in view of the weak structures of the organization they had established. But how could a subsidiary responsibility in

56. See the detailed analysis in Kolb, op. cit. n. 28, at pp. 429 et seq.

57. See RIAA, Vol. X, p. 18. 
the absence of relevant international practice or of applicable special rules be justified? The question was resolved by the arbitrators by having recourse to the principle of good faith: the arbitrators found that by not having expressly excluded their subsidiary responsibility in the Statutes of the Organization, the third parties contracting with that organization could legitimately expect such a subsidiary responsibility. And the arbitrators added that this rule flows from the general principles of law and from the principle of good faith in particular. In the words of the arbitrators: 'In default by the four States of formal exclusion of their liability, third parties which have contracted with the AOI [Arab Organization for Industrialization] could legitimately count on their liability. This rule flows from general principles of law and from good faith.' 58

What is of interest for us is not so much the well-foundedness of this finding, or the fact that the award was reversed on appeal, or further any general considerations under the law of responsibility. ${ }^{59}$ The interesting point is to see how the arbitrators attempted to bridge what was in their eyes a legal lacuna by having resort to a general principle, in this case good faith. The dynamic role of the principle is here evident. The principle constitutes a sort of head of the bridge, a sort of starting point, for the development of the law. A need is felt; a signal is given, without much legal refinement; and an evolution comes into play, which will eventually work out the specific conditions of application of such residual responsibility, according to progressively more precise and balanced criteria; or, conversely, the development will be stopped, because states or other legal actors will engage in another direction.

The principle of good faith is here not merely a source of obligation. It is also a source of law, for it objectively develops the law, it seeks to push it to some form of subsidiary responsibility of member states of international organizations. The normative power of such general principles as good faith is here apparent to a hair-blowing point.

\section{CONSTITUTIONAL FUNCTIONS OF GENERAL PRINCIPLES OF LAW IN THE INTERNATIONAL SYSTEM}

\section{$3.1 \quad$ Introductory remarks}

Many of the important general principles of law play within the legal system a role of constitutional type, which is linked to their character as norm-sources rather than simple norms. This is true of principles of all legal systems, such as good faith, proportionality, unjust enrichment; and of principles specific to

58. See 80 ILR p. 613.

59. On the question in general, see P. Klein, La responsabilité des organisations internationales (Brussels, Bruylant 1998) pp. 490 et seq. 
international law, such as non-use of force, peaceful settlement of disputes, self-determination of people, etc. These principles are among others a powerful basis for new legal developments. New needs are to be brought within the four corners of the legal system as it stands; they cannot be subsumed under the detailed rules existing at a given time; then, it is most likely that a general principle may give them provisional shelter, before new detailed rules are developed through the practice.

Consider for example, at the international plane, the principle of selfdetermination. ${ }^{60}$ In the $1940 \mathrm{~s} / 1950 \mathrm{~s}$, it was considered merely a political aspiration of disruptive effects. ${ }^{61}$ Then, in the $1960 \mathrm{~s}$, it was linked to decolonisation. In the 1970s, following the two Covenants on Human Rights, it was expanded to other situations of foreign rule (occupation) or to divided states. In the 1990s, there was added to it a whole layer of what was called internal self-determination', i.e., rights of autonomy and minority rights. Finally, since the second part of the 1990s, there is the pretendedly emerging right to democratic government which has been argued under the protection of the principle. It can thus be seen that the principle of self-determination has served as a legal storehouse for very different conceptions and needs, felt at a certain moment in the international society. These accretions from the principle have nothing pre-constituted; they emerge from real social needs, and are thus in no way conceptualist deductions from the main principle. They come to the principle, they do not in the first place flow from it. At a second stage, they may then form the basis of some fresh developments in the form of deductive reasoning. For example, some states deduced from the principle of self-determination the ability to use force in order to free from the colonial rule. ${ }^{62}$ As can be seen, the principle enriches itself by subsequent concretisations in different situations, and this process never comes to an end. The principle will probably have a completely new face in 50 years. It is proteiform, molecular, able to bind ever-new legal constructions. But at a given time, it has a relatively fixed legal meaning. 63

It is also apparent that the role displayed by the principle of self-determination cannot be compared with that of a simple norm, say about the right to lay submarine cables. The function of the principle lies at the heart of international

60. On this principle, see, e.g., C. Tomuschat, ed., Modern Law of Self-Determination (Dordrecht, Nijhoff 1993); A. Cassese, Self-Determination of People (Cambridge, Cambridge University Press 1995). See generally Jennings and Watts, eds., op cit. n. 10, at pp. 282 et seq., with many references.

61. See, e.g., the negative judgment of M. Bourquin, L'Etat souverain et l'Organisation internationale (New York, Manhattan Publishing Company 1959) pp. 213-214; or of W. Friedmann, 'General Course in Public International Law', 127 Recueil des cours (1969-II) pp. 185 et seq.

62. See H.A. Wilson, International Law and the Use of Force by Nations Liberation Movements (Oxford, Clarendon Press 1988), with many references.

63. Other similar examples could be given for other principles. 
legal dynamics; it is at the top stages of the legal order that it operates, changing the prime avenues of its functioning. These aspects of the principles have often been neglected.

At this juncture, it may be allowed to review in an extremely concise manner the main 'constitutional functions' the general principles of law display within a legal system such as the international one. These functions are situated at the level of the sources, of the main stages of the system. It is precisely because the principles are more sources than norms that these constitutional functions are theirs.

\subsection{Constitutional functions of principles}

Eight main functions may here be mentioned.

\subsubsection{Unification of the legal system}

The application of the same principles across the legal order, in its most different branches, has the obvious effect of increasing its unity by a web of interrelationships and of interdependencies. This movement exists both on the plane of international law, within its branches, and on the level of the relation of international law to internal law: general principles of law permit to reach a great fluidity of the main legal ideas, which can be transported by way of analogy from one branch to the other, from one legal system to the other. If an image be ventured, the general principles are the bees of law. Verdross has rightly put some stress on this aspect:

'Le droit des gens positif contenu dans la coutume et les conventions se compose d'une quantité de règles et précédents isolés qui, pour se ranger en système, ont besoin de certains principes directeurs. ... Sans ces principes ... le droit des gens serait non seulement muet en grande partie, mais aussi décomposé en une masse de règles et de précédents isolés, que n'unirait aucun lien commun.' 64

The principle of good faith is a prominent actor for that role. If one considers the variegated fields of application of its contents (legitimate expectations, abuse of rights, etc.) as discussed above, and especially in the light of its applicability to all sort of facts rather than a specific group of pre-defined facts, one can grasp the contribution of the principle towards some fundamental unity of some basic legal ideas. This role is to provide for legal security and for a just adjustment of pretences in bilateral and interactive relationships, and this throughout the legal order.

64. A. Verdross, 'Les principes généraux du droit applicables aux rapports internationaux', 45 RGDIP (1938) pp. 50, 52. 


\subsubsection{Flexibilization of the legal system}

A system containing only precise and fixed legal rules does not exist, because it would not be viable. Social life is at once too multifaceted and too evolutionary to be able to be caught in some strict normative categories. Thus, there must always be some more general notions, be it of the legal standard type, be it of the general principles type. It is only by these notions, oiling the wheels of the system, that this system can work out to reach satisfactory results. At the same time, by searching to gain a relatively settled legal meaning, the principles and standards try not to open up to an excessive uncertainty: the quest is for flexibility within the system with its given main axes, not for subversion of the system by completely open-ended and subjective evaluations.

Here too, the powerful role of good faith is apparent. Even if some other principles are more inherently linked with this role - especially equity - good faith permits to soften some hard results indicated by formal rules of consent (or absence of consent) by permitting to look into the actual conduct and to weigh it up under the more general aspect of equitable, and reasonable expectations created. Or, the doctrine of abuse of rights, unreasonableness, détournement de pouvoir, abuse of discretion, excess of power, and so on, allow to soften in a very circumstantial way the operation of harsh rules on formal correctness of some acts, which appear materially unbearable for society. It can be seen that in this context good faith allows the judgment of the legal actor to be nuanced and enriched, since it is not any more stopped on the level of the formal correctness of an act, but can be brought to a more concrete plane, where the whole circumstantial factual evidence is inserted into the legal process.

Consider, for example, the Preah Vihear case, or the Award of the King of Spain case, both already discussed. There, the judges had to deal with acts which, it was claimed, presented some formal defects: in the first case a treaty with a map annexed to it, where the boundary was drawn contrary to the rules laid down in the treaty; in the second case, a setting up of the arbitration when the constitutive treaty had already lapsed and, moreover, the violation of the special agreement by the arbitrator. Had the Court been obliged to stay on the level of that claims, it would have been compelled to adjudge the cases on the merits of that formal complaints, i.e., by a legal analysis of these formal acts (treaty, arbitral award) themselves. And the result may well have been in contradiction with spontaneous feelings of justice, in regard to the factual attitude of the parties involved. However, by opening up the legal analysis to this whole range of facts in the mutual relationship of the parties under the aspect of legitimate expectations, the role of the judge was enriched by a new plane. This did not compel him to neglect the formal plane, but it allowed him to get also into another, very relevant dimension. That new dimension, being circumstantial, provides for a new flexibility in adjudging the case, since the weighing of 'circumstantial behaviour' is an exercise with considerable inputs of tact and flexibility. 
The next role of general principles to be discussed, that of importing values into the legal system, has also the effect of flexibilization.

\subsubsection{Value-catalysers of the legal system}

General principles of law - and that is one of the reasons they were always so suspect to legal positivists - have the role of transporting into the legal system value considerations. They are doors of entry of the extra-legal, of the axiologic, of the social needs, and so on. By the same token, this flow of extra-legal factors is limited: there is no question to furnish a motorway to these facts, lest the legal system loose its particular characteristic of certainty and previsibility. It is rather a small path, but an important path, through which the legal system assures itself not to be completely cut, on the level of the application of the law, from the fundamental ethical values, but also from the more contingent social values and needs held at a certain moment in a particular society. Only such a minimum congruence of both assures a proper working of the law.

With respect to good faith, the moral value-standard inherent in it is immediately visible. Good faith connotes the idea of honesty and fidelity to the promise. For a long time, the principle was essentially linked to that of pacta sunt servanda, which has often been presented as a moral principle having penetrated the law. ${ }^{65}$ The same can be said of the idea of legitimate expectations, linked to the concept of responsibility for the own deeds; or of the moral principle 'nobody can take advantage of his own wrongs', another aspect of the principle of good faith. Consider, as another example, the concept of perfidy in the law of war, which is unanimously founded on the principle of good faith. It prohibits certain cats of treacherous nature, using the protections granted by the constraints of the law of warfare in order to deceive the adversary for military purposes. ${ }^{66}$ The moral content (besides the idea that the prohibition of perfidy is

65. See, e.g., Whitton, 'La règle "Pacta sunt servanda", 49 Recueil des cours (1934-III) pp. 151 et seq., 175 et seq.

66. See Art. 37, para. 1, of the Protocol I, additional to the four Geneva Conventions (1977). 'It is prohibited to kill, injure or capture an adversary by resort to perfidy. Acts inviting the confidence of an adversary to lead him to believe that he is entitled to, or is obliged to accord, protection under the rules of international law applicable in armed conflict, with intent to betray that confidence, shall constitute perfidy. The following acts are examples of perfidy: (a) the feigning of an intent to negotiate under a flag of truce or of a surrender; (b) the feigning of an incapacitation by wounds or sickness; (c) the feigning of civilian, non-combatant status; and (d) the feigning of protected status by the use of signs, emblems or uniforms of the United Nations or of neutral or other States not Parties to the conflict.' On the concept of perfidy, see P. Fauchille, Traité de droit international public, Vol. II (Paris, Rousseau 1921) pp. 125-130; H.P. Furrer, Perfidie in der Geschichte und im heutigen Kriegsvölkerrecht (Zurich, Juris Druck und Verlag 1988); M.M. Gimmerthal, Kriegslist und Perfidieverbot im Zusatzprotokoll vom 10 Juni 1977 zu den vier Genfer Rotkreuz - Abkommen von 1949 (Zusatzprotokoll I), Bochumer Schriften zur Friedenssicherung und zum humanitären Völkerrecht, Vol. IV (Bochum, Universitätsverlag Brockmeyer 1990); S. Adam, Kriegslisten und Perfidieverbot in der Geschichte des Kriegsaktionenrechts vor Abschluss der Haager Landkriegsordnung von 1899 (Frankfurt-on-Main, Peter 
vital to preserve the efficacy of the law of warfare) of the prohibition of perfidy is evident.

\subsubsection{Dynamic and evolutionary function}

General principles of law play a prominent role in legal dynamics, in the development of the law, in the adaptation of the law, in the filling of lacunae, in the transformation of stained situations. This function was the main reason why the 'general principles of law recognized by civilized nations' were inserted in the Statute of the International Court of Justice, in 1920, as applicable international law. It was considered that the Court, if it were limited to apply the two main sources of international law, namely treaties and custom, would be faced with many gaps in the body of international law. ${ }^{67}$ In effect, at the beginning of the century the process of multilateral law-making treaties binding most states of the international society was still in its inception. There were only few multilateral conventions. With some exaggeration one can say that these were mainly the Hague Conventions of 1899/1907 on peaceful settlement of disputes and the laws of war. As to customary law, it was still influenced by the old conceptions of the nineteenth century, where the practices were of slowgrowth (inveterata consuetudo) because of the relative slowness of history and of the means of communication. ${ }^{68}$ And, on the other hand, the conception that a rule could become binding on all states because it was adopted by the great powers (Concert of Europe $)^{69}$ was not any more sustainable. Finally, if some consistent practice and opinio iuris was asked for, it was anticipated that in an international society as heterogeneous as that of the beginning of the twentieth century (e.g., USSR), there would not be many common rules, either because there would be no practice at all on some new problems, or because the practice would be too split. For these reasons, it was considered that the Court should possess the right to fill the numerous gaps left by the main sources of international law, treaties and custom, by having recourse to general principles of law,

Lang 1992); M. Bothe, et al., New Rules for Victims of Armed Conflicts (The Hague, Martinus Nijhoff Publishers 1982) pp. 201-207; K. Ipsen, 'Perfidy', EPIL, Vol. 4, pp. 130-133, with further references. See also Y. Sandoz, et al., eds., Commentary on the Additional Protocols of 8 June 1977 to the Geneva Conventions of 12 August 1949 (Geneva, International Committee of the Red Cross 1987) pp. 429 et seq.

67. On this legislative history, see B. Vitanyi, 'Les positions doctrinales concernant le sens de la notion de "principes généraux de droit reconnus par les nations civilisées", 86 RGDIP (1982) pp. 48 et seq.

68. See on this point, e.g., M. Mendelson, 'The Formation of Customary International Law', 272 Recueil des cours (1998) pp. 209 et seq.

69. See, e.g., J.C. Bluntschli, Le droit international codifié (Paris, Guillaumin et cie 1870) p. 101, Art. 110: 'Lorsque les Etats rassemblés en congrès général européen sont d'accord sur certaines dispositions, celles-ci deviennent obligatoires pour tous les Etats européens'. On J.C. Bluntschli, see B. Baker Röben, 'The Method Behind Bluntschli's "Modern" International Law', 4 Journal of the History of International Law (2002) pp. 249 et seq. 
as known in the municipal experience of jurisprudence. The quest was to extend the normative reach of international law, to avoid any non liquet:

'En introduisant parmi les sources de droit international applicable les principes généraux de droit reconnus par les nations civilisées, les rédacteurs du Statut de la Cour avaient entendu développer au maximum le domaine du droit judiciairement applicable et, comme on l'a dit, pousser jusqu'à la dernière limite la productivité de ses sources. ${ }^{70}$

There was nothing really new in the Statute of the Court in codifying these principles: the practice of arbitral tribunals in the nineteenth and twentieth centuries had often had recourse to such principles and to reasoning by analogy in general.

This role of the general principles can be illustrated in many fields, e.g., in that of the principle of prescription (time-bar, laches). International tribunals have been faced with the question how to handle situations where claims were presented some 30 years of time after the incriminated events took place. Should such claims hold good, or could one apply the general principle of liberation, for the same reasons as it is done in the municipal legal systems? The international tribunals were faced with a gap in the classical sources, no treaty dealing with the matter, and no customary rule having emerged in the yet thin judicial practice of nations. They therefore had recourse to the general principle of prescription, whose legal reasons (legal certainty, equity, proper administration of justice) were held applicable also in the law of nations. A decision to this effect was rendered, for example, in the Gentini case (1903). ${ }^{71}$ In sum, it can be said that from the point of view of the completeness of the legal system, the general principles are a sort of fire brigade uti universi, able to reinforce weak points of the law or to bridge gaps in any field and in any part of its body. And thereby one is also brought back to their unity-providing function.

As to the principle of good faith, the Westland Helicopters case already quoted illustrates perfectly the position.

Moreover, it is possible to envisage that Article 2(2) of the Charter, dealing with good faith, could become the basis for fresh legal developements in the law of the UN. The article quoted applies to the member states, but also to the organs of the United Nations. ${ }^{72}$ It would be possible, always in the context of concrete legal problems and milieu of international needs and life at a given

70. See C. de Visscher, Théories et réalités en droit international public, 4th edn. (Paris, Pedone 1970) p. 419.

71. See RIAA, Vol. X, pp. 551 et seq. See also Cheng, op. cit. n. 30, at pp. 373 et seq.; B.E. King, 'Prescription of Claims in International Law', 15 BYIL (1934) pp. 82 et seq.; P.A. Verykios, La prescription en droit international public (Paris, Pedone 1934) pp. 129 et seq.; Kolb, op. cit. n. 28, at pp. 423 et seq.

72. See Kolb, op. cit. n. 28, at pp. 509-510. 
moment, to develop such legal requirements as: principles concerning the rule of law, namely the duty to respect international law as much as is feasible (e.g., for the Security Council); the duty to act transparently; or the prohibition of abuse of rights, abuse of procedure or arbitrary action, for example. There are already authors who attempted to look at the limitation of powers of the Security Council through the medium of the principle of good faith. ${ }^{73}$ The same could be done for the principle of sovereign equality. One could think here of such developments as those strengthening non-discrimination (or some form of even-handedness in the treatment of cases); the duty to give a fair hearing to all the parties concerned; the prohibition to undertake nation-building in a territory without having consulted the local people (in conjunction with self-determination); or the prohibition for the Security Council to undertake any mandatory dispute settlement without the consent of the parties (use of Chapter VII powers to achieve Chapter VI aims), for example. The point is obviously not to develop such requirements in the abstract. Rather, it is to find a legal basis when the practical needs, in a given moment in history, call for the development of such requirements, in regard to specific occurrences. The general principles of the Charter can be seen as the explorers, or the soldiers, for the conquest of such new legal landscape.

\subsubsection{Guide to interpretation and corrective function}

General principles of law have an important role also when it comes to the interpretation of legal norms. By virtue of their generality, their flexibility and their value-orientedness, they serve to a certain extent as buys and beacons in the sea of the international legal order. They can always be used as underlying reference points for a specific reasoning, whose trajectory they will influence, if not bend. This role of the principles can then go up to a point where the question is not any more one of interpretation, but becomes one of correction of a norm, or even of derogation. Such a derogatory function is visible mainly when it comes to general principles of ius cogens-character, such as the non-recourse to force. ${ }^{74}$ Some arbitrators, by virtue of some loosely formulated special agreements, have been able to interpret that corrective or derogatory function of general principles in a very broad manner. Thus, in the Mines of Aroa case (1903), the umpire said that 'in the given case, not easily to be assumed, it should occur that its precepts [those of international law] are opposed to justice

73. See E. De Wet, The Chapter VII Powers of the United Nations Security Council (Oxford, Hart 2004).

74. Thus, e.g., the Treaty of Guarantee relative to Cyprus (1960) such as interpreted by Turkey would be contrary to the Charter of the United Nations and to the peremptory principle of nonrecourse to force. Turkey interprets one provision of the treaty, which allows an intervention for protecting its nationals, as allowing it to use unilateral force. If interpreted like this, the provision is void. See on this point Repertory of Practice of the United Nations Organs, Suppl. No. 3 (1959-1966), Vol. IV (1973) pp. 210 et seq. 
... then the determination must be made by recourse to the underlying principles of justice and equity' ${ }^{75}$ In the most frequent cases, the derogation will not be as massive; the legal actor will work with infinitesimal inflections, but within these, the principle will operate and have its weight; and in the final result, in this process of adjustment of spheres of application and of mutual gravitation, the aspects of interpretation and of development of the law will merge into one another.

The examples of general principles serving in the field of interpretation (in the broad sense of the word) are numerous. Equity has served for interpreting norms about the proper assessment of damages. The principle of uti possidetis has served to interpret boundary treaties. The principle of non-use of force guides the proper interpretation of treaties containing military alliances (if power does not brutally prevail). The principle of protection of human rights has weighed on the question of state succession up to the point to assure an automatic passing of the treaties embodying that type of rights. The principle of 'commonage' has influenced the law of common spaces (sea, outer space) and the understanding of its particular norms. The principle of punishment of international crimes has found its road into the law of immunities, assuring a stricter interpretation of the last, and even a narrower confine given to their reach: one may mention here the Pinochet case as being emblematic. ${ }^{76}$ And, as to the principle of good faith, one may mention that it was often resorted to in order to reach a moderate and reasonable interpretation of the respective obligations at stake, e.g., in the North Atlantic Fisheries case (1910) ${ }^{77}$ or in the Rights of United States Nationals in Morocco case (1952). ${ }^{78}$ Or, in the words of the ICSID tribunal in Amco Asia Corporation (1983): 'Any convention ... should be construed in good faith, that is to say by taking into account the consequences of their commitments the parties may by considered as having reasonably and legitimately envisaged. ${ }^{\text {79 }}$

75. RIAA, Vol. IX, p. 445.

76. See 37 ILM (1998) pp. 1302 et seq.; 38 ILM (1999) pp. 581 et seq. See B. Zehnder, Immunität von Staatsoberhäuptern und der Schutz elementarer Menschenrechte - der Fall Pinochet (Baden-Baden, Nomos 2003).

77. RIAA, Vol. XI, pp. 167 et seq., 187-188. See Kolb, op. cit. n. 28, at pp. 269-270. The point was that the legislative power of the UK for certain spaces under its sovereignty was limited by the existence of rights for US citizens; hence an obligation for the UK to exercise its jurisdiction is taking reasonably, in good faith, account of these US rights.

78. ICJ Reports (1952) pp. 176 et seq., 211-212. See Kolb, op. cit. n. 28, at pp. 270. The point was the correct interpretation of some custom duties under a convention. The Court rejects the strict interpretations given by the two sides and holds that the principle of good faith and of reasonableness must be the measure to be followed in the specific case.

79. 23 ILM (1984) p. 359. 


\subsubsection{Autonomous source of law (choice of law)}

It has already been mentioned that general principles of law may serve as the basis of autonomous legal reasoning. They then serve to free the legal actor from the constraints of positive law and to seek in more lofty and general areas a satisfactory solution for the single case submitted to him. In this case, a legislative power is transferred to the legal actor, but it is limited to the specific case at issue. Broadly speaking, such cases can be analysed as a power to decide the case ex аеquo et bono. Such powers are often conferred on arbitrators in the context of quasi-international contracts, i.e., commercial contracts between a state and a private person or corporation. A state legal order is here suspect, since the private part wishes to escape the application of any municipal law, suspected to lean too much towards the states interests; this is obviously particularly true of the municipal law of the state with whom the contract is concluded. Thus, recourse to general principles of good faith, of good will and of equity may serve as a basis of compromise, with which both parties may well live. ${ }^{80}$ The 'productivity' of good faith (or any other principle) is here pushed to its apogee, since the principle is the basis for legislation in the individual case.

\subsubsection{Necessary complement to a series of legal rules}

A series of legal rules require the complement of a principle in order to be put properly at work. Thus, for example, there can be no proper application of the important norm on self-defence in international law without the corollary application of the principles of necessity and of proportionality, in order to measure the lawfulness of a particular application of the norm in a given case. The International Court of Justice had thus recourse to these principles when applying self-defence, namely in the Nicaragua case (Merits, 1986) ${ }^{81}$ and in the Oil Platforms case (Merits, 2003). ${ }^{82}$ The same could be said of the law of counter-measures. ${ }^{83}$ Moreover, no assessment of damages in a specific case can be performed without the complement of some principles such as 'fault', 'causality', 'proportion', 'reciprocity' (set-off!), 'equity', etc. This role of general principles is evinced in particular through the jurisprudence.

80. See the already mentioned Sapphire International Petroleum case (1963), supra n. 38. The applicable law was 'les principes de la bonne foi et de la bonne volonté ...'.

81. ICJ Reports (1986) pp. 122-123, para. 237.

82. See especially paras. 51 and 73 et seq. See also the Legality of Threat or Use of Nuclear Weapons, Advisory Opinion of 8 July 1996, ICJ Reports (1996) pp. 245-246, paras. 41 et seq.

83. See Arts. 49-54 of the Draft on State Responsibility for Internationally Wrongful Acts (2001) by the International Law Commission: J. Crawford, The International Law Commission's Articles on State Responsibility (Cambridge, Cambridge University Press 2002) pp. 281 et seq. See also L.A. Sicilianos, Les réactions décentralisées à l'illicite (Paris, LGDJ 1990) pp. 20 et seq., 273 et seq. 
As to good faith, its complementary role is mostly that of a principle of interpretation of extremely dense and multifaceted contents: ${ }^{84}$ interpretation according to the spirit more than according to literal meanings; reasonable interpretation; prohibition of abusive interpretations; prohibition of fraud to the law; ordinary meaning-presumption (legitimate expectation!); falsa demonstratio non nocet; modification of a text by acquiescence or estoppel; interpretation in favorem validitatis; interpretation contra proferentem; etc. All these aspects have been linked to the principle of good faith. And as no text (or indeed norm) can stand without interpretation, good faith is a necessary complement to the practical understanding and execution of these texts and norms.

\subsubsection{Facilitation of legislative compromises}

The situation often occurs that in a conference or in a negotiation a point is reached where a compromise solution on any concrete terms seems impossible because of the too divergent interests. It then often happens that the delegations agree on some formulae, which mask their real divergences behind a veil of lofty and apparently non-committing words. It is said that they agreed to disagree. Be that as it may, what is certain is that the pressure to conclude an agreement and not to come back with empty hands was greater than the temptation to separate on a failure. In such cases, general principles of law can provide very useful services in trying to bridge the gaps of interests without yet fixing a precise legal regime. It will be possible to agree in the quite heated stage if the negotiations on some general principles, leaving the concrete solution to the future. This has the further advantage that the disputes in the future are most likely to be on some specific point in a specific context; and then it will be easier to find a solution, either in direct contact or through third-party settlement. There is thus a sort of delegation of quasi-legislative powers to a later stage, for the future legal actors which will be confronted to specific cases. It is expected that they will be able to do so in a new light, and perhaps a great deal of time later, when the divergences which had burdened the conference will not be any more felt as heavily. This is often done through the insertion of principles of reasonableness, ${ }^{85}$ of 'reasonable measures', of 'due regard', of 'equitable apportionment', etc.

As to good faith, Article 300 of the Montego Bay Convention of the Law of the Sea to some extent plays such a role. ${ }^{86}$ It reads as follows: 'States parties shall fulfil in good faith the obligations assumed under these Convention and shall exercise the rights, jurisdiction and freedoms recognised by

84. See Kolb, op. cit. n. 28, at pp. 260 et seq.

85. See, e.g., O. Corten, L'utilisation du 'raisonnable' par le juge international (Brussels, Bruylant 1997) pp. 270 et seq.

86. See Kolb, op. cit. n. 28, at pp. 474-476. 
this Convention in a manner which would not constitute an abuse of rights.' This formula takes the place of the old 'due regard'-clause inserted into the four Geneva Conventions of 1958. The point was that the Convention is an enormous compendium of the most diverging rights and duties granted to states with fundamentally opposed interests: e.g., the sea-faring states and the coastal states. The Convention attempted to regulate as much as possible these conflicts of interests in assigning in positive law relative preferences. This constitutes the body of the treaty. But when it came to differences not able of concrete solutions, it was thought useful to insert a general clause, that of Article 300, with its reference to good faith and abuse of rights. Its function is to permit in later stages, when applying the Convention, to reach for equilibrium of interests in a specific case; it opens the way for ad hoc reasonable adjustments. If one bears in mind that the Convention organises a compulsory dispute settlement scheme, the constitutional function of Article 300 becomes apparent. It gives the opportunity, indeed the mandate, to the legal actor seized to weigh carefully up the conflicting interest in a specific case, and to look for a balanced and equitable solution for which no specific rule could be found in the conference. In the hands of those arbitrators or conciliators, the clause will become a legislative tool, able of providing solutions of conflicts in the plenitude of circumstantial assessments, and to thereby develop the law of the sea.

Thus, the general principle of good faith (and its vassal, the prohibition of abuse of rights) permitted at once to adopt the Convention by delegating some conflict-solution to later stages; and to find later in time, on a case-by-case basis, adequate solutions to the problems which will be raised, by way of a praetorian development of the law.

\section{CONCLUSION}

The foregoing passages have attempted to show through an analysis of aspects often neglected the essential roles general principles of law perform in the body of the law of nations. Some particular stress has been laid on the principle of good faith, on account of its great importance and on account of the subject matter of this article. The law of general principles is constitutional law in the fullest sense of the word. It is placed on the level of sources, of development of the law, of essential metabolistic functions within the legal order. By the richness of their normative content, by their unique faculty of ubiquity, by their ability to give rise to a multiplicity of normative 'concretizations', the principles are among the most real forces in international law. The relative lack of interest in them - furthered by a positivistic legal thinking attached only to the particular to the detriment of the general (which is accused to be vague) - should give way to a renewed interest in this fascinating branch of the law. 